\title{
THE CHANGES IN PLASMA POTASSIUM LEVEL AFTER EPINEPHRINE IN NORMAL HUMAN BEINGS AND IN PERSONS WITH EPILEPSY
}

\author{
By ABRAHAM DURY, JACOB W. HOLLER, AND CALEB SMITH with THE TECHNICAL \\ ASSISTANCE OF THOMAS N. JOHNSTON
}

\author{
(From The Dorn Laboratory for Medical Research, Bradford Hospital, Bradford, Pa.; and the \\ Departments of Medicine and Surgery, Bradford Hospital and the University of \\ Rochester School of Medicine and Dentistry, Rochester, N. Y.)
}

(Submitted for publication November 8, 1951 ; accepted February 25, 1952)

Biochemical studies directed toward finding a difference in the blood composition of normal and epileptic subjects have thus far been unfruitful. In the course of other studies at this laboratory (1), it was observed that the pattern of change in the plasma potassium level after an injection of epinephrine in a subject afflicted with epilepsy was different from that found in normal subjects similarly treated. An investigation was therefore undertaken to measure the changes in the concentration of plasma potassium, sodium and glucose at several time-intervals after an injection of epinephrine in epileptic patients and in normal human subjects. The results of this investigation showed that there was a significant difference in the pattern and extent of change in the plasma potassium level of epileptic subjects compared to normals subsequent to administration of epinephrine. There was no difference in the plasma sodium levels and only a probably significant difference in the extent of change in the plasma glucose level.

\section{MATERIALS AND METHODS}

Normal humans and patients with idiopathic epilepsy of both sexes were the subjects of this study. They were not told the nature of the tests to be performed except that several venous blood samples were to be taken for analyses. Eight of the subjects were patients of local physicians and five others were patients residing at Craig Colony, N. Y.1 These patients had been taking prescribed amounts of one of the several anti-convulsant drugs and/or phenobarbital for one to several years. All of the epileptic subjects were well nourished individuals with no other complaints than their epileptic condition. They all were engaged in a variety of outdoor and indoor activities (three of the subjects were housewives; three were attending Junior High School; three were

1 Grateful acknowledgment is made to Dr. Henry Brill, Medical Director, Craig Colony, N. Y., of the State of New York Department of Mental Hygiene, and the Hospital staff for their cooperation. engaged in light mechanical jobs; and five of the subjects performed a variety of custodial duties). The normal subjects in this study were members of the staffs of the hospital and laboratories.

All of the tests were done in the morning with the subjects in a post-absorptive state. Immediately after the initial fasting blood sample had been obtained for the determination of baseline values, the subjects were given an intramuscular injection of $0.4 \mathrm{ml}$. of epinephrine (Adrenaline Chloride aq.; Parke, Davis \& Co., $1: 1,000$ ). Blood samples were then obtained without stasis from one of the antecubital veins at four, 20,60, and $120 \mathrm{~min}$ utes after the epinephrine injection. The blood was transferred to tubes containing 2 drops of heparin (Liqeamin, Organon, $10 \mathrm{mg} . / \mathrm{ml}$.) and immediately centrifuged. The plasma was immediately separated and aliquots taken for the various biochemical determinations. The plasma levels of sodium and potassium (m.eq./L) were determined with the aid of an internal standard lithium flame photometer using a dual-optical system of the type described by Berry, Chappell, and Barnes (2). Aliquots completely clear of hemolysis were used in these determinations. The plasma glucose levels (mg.\%) were determined at first by the method of Somogyi-SchafferHartmann (3) and then in most of the investigation by the photometric method of Kingsley and Reinhold (4).

\section{RESULTS}

The age, sex, number of grand mal seizures per month, and other information relevant to the epileptic subjects used in this study are shown in Table I. These subjects also experienced a number of petit mal attacks each month. They had been definitely diagnosed by their physicians as having idiopathic epilepsy. This was confirmed by the electroencephalograms ${ }^{2}$ of all but one subject thus tested.

The mean per cent change ( \pm S. E.) in the

${ }^{2}$ Grateful acknowledgment is made to Dr. Robert $H$. Israel, Superintendent, Warren State Hospital, Commonwealth of Pennsylvania Department of Welfare, for recording and interpreting the electroencephalograms of several of the epileptic subjects. 
TABLE I

Pertinent data of epileptic subjects used in tests

\begin{tabular}{|c|c|c|c|c|c|c|}
\hline Patient & Age & Sex & $\begin{array}{c}\text { Number of } \\
\text { seizures } \\
\text { per } \\
\text { month }\end{array}$ & $\underset{\text { report }}{\text { E. E. G. }}$ & $\begin{array}{l}\text { Last at- } \\
\text { tack be- } \\
\text { fore test } \\
\text { (wks.) }\end{array}$ & Medication \\
\hline $\begin{array}{l}\text { Wi } \\
\text { Be } \\
\text { Ben } \\
\text { Hu } \\
\text { Go } \\
\text { Wa } \\
\text { Ro } \\
\text { Co } \\
\text { Ma } \\
\text { Man* } \\
\text { Ron* } \\
\mathrm{Mu}^{*} \\
\mathrm{Ca}^{*} \\
\mathrm{Ha}^{*}\end{array}$ & $\begin{array}{l}62 \\
12 \\
13 \\
36 \\
11 \\
22 \\
24 \\
31 \\
57 \\
28 \\
32 \\
47 \\
21 \\
42\end{array}$ & $\begin{array}{l}\mathbf{F} \\
\mathbf{F} \\
\mathbf{M} \\
\mathbf{M} \\
\mathbf{F} \\
\mathbf{M} \\
\mathbf{M} \\
\mathbf{M} \\
\mathbf{M} \\
\mathbf{M} \\
\mathbf{M} \\
\mathbf{M} \\
\mathbf{M}\end{array}$ & $\begin{array}{c}2-4 \\
2-4 \\
2-4 \\
1 \\
2 \\
2 \\
3-5 \\
3-4 \\
1 \\
2 \\
2 \\
3-4 \\
2 \\
2\end{array}$ & $\begin{array}{l}\text { E. posit. } \\
\text { E. posit. } \\
\text { E. posit. } \\
\text { ? E. posit. } \\
\text { E. posit. } \\
\text { E. posit. } \\
\text { No test } \\
\text { E. posit. } \\
\text { ? Normal } \\
\text { E. posit. } \\
\text { No test } \\
\text { No test } \\
\text { No test } \\
\text { No test }\end{array}$ & $\begin{array}{r}1 \\
1 \\
0.5 \\
1 \\
1 \\
1 \\
0.5 \\
4 \\
2 \\
2 \\
1 \\
0.5 \\
1\end{array}$ & $\begin{array}{c}\text { Dilantin } \\
\text { Dilantin } \\
\text { Dilantin } \\
\text { Dil. and PhB. } \\
\text { Dilantin } \\
\text { Dilantin } \\
\text { Dilantin } \\
\text { Dilantin } \\
\text { None } \\
\text { Dil. and PhB. } \\
\text { Mes. and PhB } \\
\text { PhB. } \\
\text { Dil. and PhB. } \\
\text { PhB. }\end{array}$ \\
\hline
\end{tabular}

* Residents of Craig Colony.

† Grand Mal seizures.

Dil. is Dilantin, Tid.

Mes. is Mesantoin, Tid.

$\mathrm{PhB}$. is Phenobarbital, Tid.

plasma potassium level at four, 20, 60, and 120 minutes after epinephrine injection in the normal and epileptic groups of subjects is shown in Table II. It is evident from an inspection of these data that the plasma potassium levels were different after epinephrine in the two groups of subjects. In the epileptic group the mean plasma potassium level was found to be depressed from the initial level at four minutes after the epinephrine and persisted thus for a relatively prolonged time compared to the changes found in the normal group. Tests for statistical significance of the difference between the means of the two groups of subjects in each time-interval after epinephrine showed that the mean per cent change in the epileptic group was significantly different from the normals in all the periods except 20 minutes after epinephrine. It was in this pe-

TABLE II

The change in plasma potassium levels in normal and epileptic subjects following an intramuscular injection of epinephrine*

\begin{tabular}{c|c|c|c|c}
\hline \multirow{2}{*}{ Subjects } & \multicolumn{4}{|c}{ Minutes after epinephrine injection } \\
\cline { 2 - 4 } & 4 & 20 & 60 & 120 \\
\hline $\begin{array}{c}\text { Normals (11) } \\
\text { Epileptics (15) }\end{array}$ & $\begin{array}{c}+1.6 \pm 1.1 \dagger \\
-5.4 \pm 1.6 \ddagger\end{array}$ & $\begin{array}{c}-6.5 \pm 1.3 \\
-10.2 \pm 1.7\end{array}$ & $\begin{array}{c}+1.0 \pm 1.4 \\
-7.7 \pm 1.7 \ddagger\end{array}$ & $\begin{array}{c}+6.7 \pm 2.6 \\
-2.8 \pm 1.6 \ddagger\end{array}$ \\
\hline
\end{tabular}

* $0.4 \mathrm{mg}$. epinephrine injected immediately after fasting blood sample was taken.

$\dagger$ Mean per cent change ( \pm S. E.) from the pre-injection mean potassium level.

‡ Value of " $P$ " for difference between the means was significant ( $P=<0.01$ in each period).

Number of subjects in each group is in the parentheses.
TABLE III

The change in plasma sodium levels in normal and epileptic subjects following an intramuscular injection of epinephrine*

\begin{tabular}{c|c|c|c|c}
\hline \hline \multirow{2}{*}{ Subjects } & \multicolumn{4}{|c}{ Minutes after epinephrine injection } \\
\cline { 2 - 5 } & 4 & 20 & 60 & 120 \\
\hline $\begin{array}{c}\text { Normals (11) } \\
\text { Epileptics (15) }\end{array}$ & $\begin{array}{c}+0.8 \pm 0.4 \dagger \\
-0.4 \pm 0.7\end{array}$ & $\begin{array}{l}+0.8 \pm 0.5 \\
+0.2 \pm 0.5\end{array}$ & $\begin{array}{l}+0.6 \pm 0.5 \\
+0.3 \pm 0.5\end{array}$ & $\begin{array}{l}+0.5 \pm 0.5 \\
-0.6 \pm 0.7\end{array}$ \\
\hline
\end{tabular}

* $0.4 \mathrm{mg}$. epinephrine injected immediately after fasting blood sample was taken.

+ Mean per cent change ( $\pm S$. E.) from mean pre-injection sodium level.

" $T$ " tests for difference between the means were not significant in all periods.

Number of subjects in each group is in the parentheses.

riod that the plasma potassium level in the normal group was maximally depressed from the pre-injection level.

In Table III is shown the mean per cent change ( \pm S. E.) in the levels of plasma sodium at the several time-intervals after epinephrine in the two groups of subjects. It is apparent that the concentration of sodium was unchanged from the respective initial levels in both groups of subjects. The difference between the means of the two groups was not statistically different.

The mean per cent change ( \pm S. E.) in the levels of plasma glucose after epinephrine in the normal and epileptic groups is presented in Table IV. Inspection of these data show that both groups experienced a hyperglycemic response following the epinephrine injection. Although the pattern of change was the same in both groups of subjects, it is apparent that the mean per cent change was greater in the normal group. Tests for statistical significance of the difference between

TABLE IV

The change in plasma glucose levels in normal and epileptic subjects following an intramuscular injection of epinephrine*

\begin{tabular}{c|c|c|c|c}
\hline \multirow{2}{*}{ Subjects } & \multicolumn{4}{|c}{ Minutes after epinephrine injection } \\
\cline { 2 - 4 } & 4 & 20 & 60 & 120 \\
\hline $\begin{array}{c}\text { Normals (11) } \\
\text { Epileptics (15) }\end{array}$ & $\begin{array}{c}+2.8 \pm 0.9+ \\
+2.4 \pm 2.4\end{array}$ & $\begin{array}{c}+42.4 \pm 5.3 \\
+23.7 \pm 3.9 \\
0.008 \ddagger\end{array}$ & $\begin{array}{c}+49.0 \pm 6.7 \\
+31.5 \pm 6.5\end{array}$ & $\begin{array}{c}+1.2 \pm 4.6 \\
+1.1 \pm 4.8\end{array}$ \\
\hline
\end{tabular}

* $0.4 \mathrm{mg}$. epinephrine injected immediately after fasting blood sample was taken.

$\dagger$ Mean per cent change $( \pm S$. E.) from the mean pre-injection glucose level.

‡ Value of "P" of difference between the means.

Number of subjects in each group is in the parentheses. 
TABLE $v$

The initial plasma potassium levels and levels of maximum change after an intramuscular injection of $0.4 \mathrm{mg}$. epinephrine in normal and epileptic subjects

\begin{tabular}{|c|c|c|c|c|c|}
\hline \multicolumn{3}{|c|}{ Normal subjects } & \multicolumn{3}{|c|}{ Epileptic subjects } \\
\hline \multicolumn{2}{|c|}{ Potassium (m.eq./L) } & \multirow{2}{*}{$\begin{array}{c}\% \\
\text { change }\end{array}$} & \multicolumn{2}{|c|}{ Potassium (m.eq./L) } & \multirow{2}{*}{$\begin{array}{c}\% \\
\text { change }\end{array}$} \\
\hline $\begin{array}{c}\text { Before } \\
\text { epinephrine }\end{array}$ & $\begin{array}{c}\text { After } \\
\text { epinephrine }\end{array}$ & & $\begin{array}{c}\text { Before } \\
\text { epinephrine }\end{array}$ & $\begin{array}{c}\text { After } \\
\text { epinephrine }\end{array}$ & \\
\hline $\begin{array}{l}4.4 \\
4.5 \\
4.0 \\
4.15 \\
4.15 \\
4.28 \\
4.83 \\
3.93 \\
4.95 \\
4.60 \\
4.27\end{array}$ & $\begin{array}{l}4.2 \\
4.0 \\
3.8 \\
4.08 \\
3.98 \\
4.18 \\
4.6 \\
3.4 \\
4.38 \\
4.13 \\
4.18\end{array}$ & $\begin{array}{r}-4.5 \\
-11.1 \\
-\quad 5.0 \\
-\quad 1.7 \\
-\quad 5.3 \\
=2.3 \\
-\quad 4.7 \\
-13.5 \\
-11.5 \\
-10.2 \\
-\quad 2.1\end{array}$ & $\begin{array}{l}3.9 \\
4.6 \\
4.55 \\
4.32 \\
5.0 \\
4.3 \\
4.9 \\
4.28 \\
5.4 \\
4.85 \\
4.05 \\
4.48 \\
4.53 \\
4.56 \\
3.9\end{array}$ & $\begin{array}{l}3.4 \\
4.2 \\
4.1 \\
3.65 \\
4.16 \\
3.35 \\
3.85 \\
4.0 \\
4.7 \\
4.33 \\
3.44 \\
3.87 \\
3.95 \\
4.0 \\
3.4\end{array}$ & $\begin{array}{l}-12.8 \\
-\quad 8.7 \\
-9.9 \\
-15.5 \\
-16.8 \\
-22.1 \\
-21.4 \\
-6.5 \\
-13.0 \\
-10.7 \\
-15.0 \\
-13.6 \\
-12.8 \\
-12.3 \\
-12.8\end{array}$ \\
\hline $4.37 \pm .10^{*}$ & $4.08 \pm .09$ & $-6.5 \dagger$ & $4.51 \pm .10$ & $3.89 \pm .10$ & -13.6 \\
\hline
\end{tabular}

$*$ Mean \pm S. E.

$\dagger$ Mean.

the means of the two groups in each time-interval after epinephrine revealed that the difference was highly significant in the 20 minute period and probably significantly different ("P" equaled 0.06 ) in the 60 minute period.

It is evident that the change in plasma potassium level after epinephrine was the only one of the three (change in plasma level of potassium, sodium, glucose) which was significantly different in the epileptic group from that in the normal group. The data in Table $\mathrm{V}$ indicate that there was no difference between the post-absorptive

TABLE VI

The mean per cent changes in plasma potassium levels after a placebo injection* and after an injection of epinephrine in the same epileptic subjects

\begin{tabular}{c|c|c|c|c}
\hline \hline \multirow{2}{*}{ Injection } & \multicolumn{4}{|c}{ Minutes after injection } \\
\cline { 2 - 5 } & 4 & 20 & 60 & 120 \\
\hline $\begin{array}{c}\text { Placebo (7) } \\
\text { Epinephrine (7) }\end{array}$ & $\begin{array}{c}-0.6 \pm 2.3 \dagger \\
-5.9 \pm 2.0 \\
0.1 \ddagger\end{array}$ & $\begin{array}{c}-2.0 \pm 2.6 \\
-12.2 \pm 2.4 \\
0.02\end{array}$ & $\begin{array}{c}-1.4 \pm 2.3 \pm 2.0 \\
0.01\end{array}$ & $\begin{array}{r}0.0 \pm 2.7 \\
-4.8 \pm 2.5 \\
0.2\end{array}$ \\
\hline
\end{tabular}

* $0.4 \mathrm{ml}$. of physiological saline was injected intramuscular as the placebo; and $0.4 \mathrm{mg}$. of epinephrine $(1: 1,000)$ was injected as the test agent.

$t$ Mean $\pm S$. E.

$\ddagger$ Value of " $P$ " of the difference between the means.

Number of subjects in each group is in parentheses. plasma potassium levels in the normal and epileptic groups. It is also evident that there was a significant difference in the extent of maximum depression in the potassium level after epinephrine. These data therefore show that the initial potassium level could not have been a determinant factor in the difference between the two groups in the extent of plasma potassium change which was found after injection of epinephrine.

In Table VI are presented the mean per cent changes in the plasma potassium level of several epileptic subjects determined after epinephrine and again after a placebo injection of an equal amount of physiological saline. The two tests were performed in the same individuals about two weeks apart. Inspection of these data show that the placebo had not affected the potassium concentration. This is obviously different from the relatively large depression in the plasma potassium level found in these same subjects after epinephrine administration, and significantly changed at 20 and 60 minutes.

\section{DISCUSSION}

Several investigators have reported (5-7) in the past that both epinephrine and insulin administration in man and animals were followed by a fall in the plasma potassium level at approximately 20 minutes after their administration. The results presented in this paper showed that following an intramuscular injection of $0.4 \mathrm{mg}$. of epinephrine, there was a significant difference in the pattern of change in potassium level and the extent of fall in potassium level in subjects with idiopathic epilepsy from that found in normal human subjects. The level of plasma sodium was not affected by epinephrine administration in either group of subjects. It is of interest that Holler, Burton, Dury, and Keutmann (8) found, in a group of Addisonian subjects, an extensive and prolonged depression of the potassium level after the injection of $0.4 \mathrm{mg}$. of epinephrine, which generally resembled the pattern of changes in potassium level presented here in the epileptic group.

In a series of animal studies recently reported by Dury (9-11) it was shown that epinephrine induced a fall in plasma potassium level in normal, hypophysectomized, adrenalenucleated, and adrenalectomized rats. It was also shown that epinephrine-pretreatment.protected adrenalectomized 
rats from an experimental procedure which induced a fatal hyperkalemia in untreated adrenalectomized rats. These data indicated that epinephrine's effect upon the plasma potassium level did not require the mediation of the pituitaryadrenocortical system. The animal studies therefore indicate that epinephrine is related to a fall in plasma potassium level, probably due to a specific effect. The results presented here, showing a difference in the effect of epinephrine upon the plasma potassium level in normal and epileptic subjects, cannot, however, be explained from the data in this paper. However, a basis for explanation and speculation of this difference in potassium change in the normal and epileptic subjects is indicated by the results of a similar investigation in patients with Addison's disease (8) and in certain animal studies $(9,10)$. Holler and associates (8) found that the pattern of plasma po-

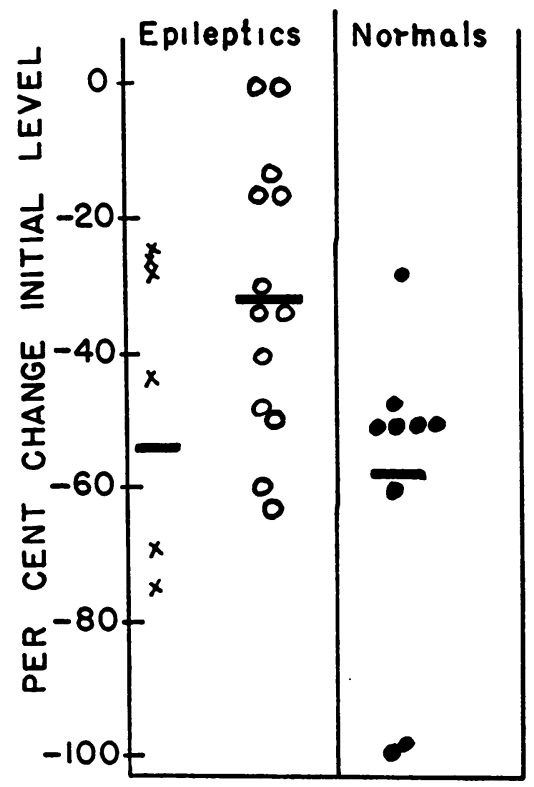

Fig. 1. Per Cent Changes in Number of Circulating Eosinophiles

Two hours after $0.4 \mathrm{mg}$. epinephrine, I. M., in epileptic (open circles) and normal (closed circles) subjects; and three hours after $25 \mathrm{mg}$. ACTH in epileptics (represented by $\mathbf{X})$. Solid bar indicates mean change.

Statistical analysis of eosinophil data (\% change after epinephrine)

\begin{tabular}{c|c|c|c}
\hline Normals & Epileptics & $t$ & "P"* \\
\hline$-59 \pm 8 \dagger$ & $-31 \pm 5$ & 3.8 & 0.001
\end{tabular}

* Level of significance of difference between the means. $\dagger$ Mean \pm S. E. tassium change after epinephrine in Addisonian subjects was similar to that reported here for epileptic subjects, but the extent of change in the former group was greater. In the animal studies it had been noted that the extent of fall in potassium level 60 minutes after epinephrine was greater in adrenalectomized than in normal rats. Whether the difference in plasma potassium change after epinephrine in normal and epileptic subjects is related to a difference in the functional status of the adrenal cortex or some other factor(s) must await further investigation. However, evidence admittedly of a preliminary nature which suggests this area of relationship is presented in Figure 1. The per cent change in the number of circulating eosinophiles is shown in the form of a scatter diagram for normal and epileptic subjects after epinephrine injection and after an injection of $25 \mathrm{mg}$. of ACTH. The eosinophiles were enumerated by the method of Randolph (12). Statistical analysis of the results showed that the mean per cent change was significantly lower in the epileptic group compared to the response obtained in the normal group. It is noteworthy that Aird and Gordon (13) recently reported that the frequency of epileptic seizures was decreased in epileptics treated with desoxycorticosterone.

\section{SUMMARY}

The changes in plasma levels of potassium, sodium, and glucose at four, 20,60, and $120 \mathrm{~min}$ utes after an intramuscular injection of $0.4 \mathrm{mg}$. of epinephrine were determined in a group of normal human subjects and a group of subjects with idiopathic epilepsy.

It was shown that following the epinephrine administration there was a significant difference in the extent of plasma potassium fall and the pattern of change in the epileptic group as compared to that in the normal group. The plasma sodium levels were not affected in either group. A possible area which suggests a basis for an explanation of the results was discussed.

\section{REFERENCES}

1. Dury, A., Holler, J. W., and Smith, C., Unpublished data.

2. Berry, J. W., Chappell, D. G., and Barnes, R. B., Improved method of the flame photometry. Indust. \& Engin. Chem., Analyt. Ed., 1946, 18, 19. 
3. Somogyi, M., Determination of blood sugar. J. Biol. Chem., 1945, 160, 69.

4. Kingsley, G. R., and Reinhold, J. G., The determination of true glucose in blood by reduction of ferricyanide. J. Lab. \& Clin. Med., 1949, 34, 713.

5. D'Silva, J. L., Action of adrenaline on the serum potassium. J. Physiol., 1937, 90, 303.

6. Keys, A., The response of the plasma potassium level in man to the administration of epinephrine. Am. J. Physiol., 1938, 121, 325.

7. Castleden, L. I. M., The effect of adrenalin on the serum potassium level in man. Clin. Sc., 1938, 3, 241.

8. Holler, J. W., Burton, R. B., Dury, A., and Keutmann, E. H., The effect of epinephrine on the serum potassium levels in adrenal insufficiency. Unpublished.
9. Dury, A., The effect of epinephrine and insulin on the plasma potassium level. Endocrinology, 1951, 49, 663.

10. Dury, A., and Johnston, T. N., Changes in plasma and tissue water and electrolytes after epinephrine administration in rats. Proc. Soc. Exper. Biol. \& Med., 1951, 78, 425.

11. Dury, A., Epinephrine protection against fatal hyperkalemia in adrenalectomized rats. Proc. Soc. Exper. Biol. \& Med., 1951, 77, 199.

12. Randolph, T. G., Differentiation and enumeration of eosinophils in the counting chamber with a glycol stain; a valuable technique in appraising ACTH dosage. J. Lab. \& Clin. Med., 1949, 34, 1696.

13. Aird, R. B., and Gordon, G. S., Anticonvulsive properties of desoxycorticosterone. J. A. M. A., 1951, 145,715 . 